\title{
Translata Proficit: Revisiting John Florio's translation of Michel de Montaigne's Les Essais
}

\author{
Oana-Alis Zaharia \\ "Dimitrie Cantemir" University, Romania
}

\begin{abstract}
This paper considers John Florio's famous translation of Montaigne's Essays as a source of invaluable insight into the Elizabethan practice and theory of translation. In the letter addressed to the reader, Florio strongly advocates the use of translation as a means of advancing knowledge and developing the language and culture of a nation. Echoing the Elizabethan debate between the defenders and detractors of translation, his preface provides precious information on the various Elizabethan understandings of the role of translation. Casting himself in the role of a "foster-father", Florio foregrounds the idea of translation as rewriting of the original text into a new creation. While most scholars have emphasised solely Florio's augmentation of Montaigne's text and his fondness for addition, paraphrase and alliteration, the present paper intends to demonstrate that this dimension of his translation is frequently complemented by Florio's tendency to render the text closely, even word for word at times.
\end{abstract}

KEYWORDS: John Florio, Montaigne's Les Essais, Elizabethan practice and theory of translation, rewriting, fondness for words, literal translation.

\section{Introduction}

1603 is the year that saw the publication of one of the most popular and influential Elizabethan translations - John Florio's rendering of Michel de Montaigne's Les Essais - which proved to be an instant success in Elizabethan England. The translation continued to raise interest and circulate extensively for the next half century being republished in 1613 and 1632 .

$$
\text { (E) ederi } 22 \text { (2012: 115-136) }
$$


The immense influence of Florio's translation in sixteenthcentury England, particularly its connections to Shakespeare's drama, turned it into an important point of interest for most scholars concerned with the theory and practice of early modern English translation. In Translation: An Elizabethan Art (1931), the first scholarly study on sixteenth-century English translations, F. O. Matthiessen included Florio's translation, next to Sir Thomas Hoby's Courtier (1561), Thomas North's Plutarch's Lives (1579) and Philemon Holland's published translations from Livy (1600) and from Suetonius (1606), in a group of five that comprised what he deemed to be the most important Elizabethan translations in prose. To Matthiessen - for whom "a study of Elizabethan translations is a study of the means by which the Renaissance came to England" (1931:3) - Florio's greatest gift was the ability to make Montaigne's Essays come to life for the Elizabethan imagination (1931:130).

A close analysis of Florio's translation has been recently undertaken by Massimiliano Morini in Tudor Translation in Theory and Practice (2006), the first attempt since Matthiessen's Translation to assess a wider range of sixteenth-century English translations. Claiming that the body of scholarly work on medieval and postTudor translation is more coherently organized and documented than that on the Tudor period, Morini attempts to "bridge" this gap and provide a theory of sixteenth-century translation based on an inductive method. He argues that the lack of coherence which characterises Tudor translation theory is mainly due to the period's transition from "medieval" to "modern" theories of translation (Morini 2006:13). While Florio's translation bears the marks of the new humanist Italian-influenced theories and their emphasis on an exact and clear rendering of the original texts (Morini 2006:17), it also foregrounds the main features of the Elizabethan style and taste: "Montaigne's inventio and dispositio are kept and replicated in English, but his elocution (style) is transformed and adapted as happens so often in the Renaissance, to Florio's taste and the habits of his audience" (Morini 2006:84).

The audience of Florio's translation, its impact on the household education of young noblemen and noblewomen and the importance of humane learning within this pedagogical process constituted the topic of a series of insightful articles written by Warren Boutcher, to 
whom our own discussion of these issues is heavily indebted (2002, 2004).

Following this line of research on early modern translations and applying the recent developments in translation studies (Lefevere 1992; Lefevere and Bassnett 1998; Venuti 1995), the present paper attempts to provide some new insights into the critical exploration of Florio's translation of Montaigne. In the letter addressed to the courteous reader, Florio champions translation as the most useful route for advancing knowledge and developing the language and culture of a nation. Echoing the Elizabethan debate between the defenders and detractors of translation, his preface provides invaluable information on the various Elizabethan understandings of the role of translation. Casting himself in the role of a "foster-father," Florio highlights the idea of translation as rewriting of the original text into a new creation. While scholars such as F.O. Matthiessen, Massimiliano Morini and Philippe Desan have emphasised in their studies solely Florio's augmentation of Montaigne's text, his fondness for addition, doubling, paraphrase and alliteration, the present paper sets out to demonstrate that this dimension of his translation is frequently complemented by Florio's tendency to render the text closely, even word for word at times.

\section{The influence of Montaigne's Essays in Elizabethan England}

After Montaigne's death in 1592, the definitive edition of his Essays was published in Paris in $\mathbf{1 5 9 5}$ by Marie le Jars de Gournay, Montaigne's literary executor. That same year the Englishman, Edward Aggas, is mentioned in the Stationers' Register as owning a copy of The Essays of Michaell Lord Mountene (Matthiessen 1931:103). If this was an early translation, as the title suggests, there are no traces left of it. However, John Florio himself mentions in the epistle preceding his translation of Les Essais that "Seven or eight of great wit and worth" (A5) had unsuccessfully attempted to English Montaigne's Essays before him. Similarly, in the Preface to his own book of Essayes (160o), William Cornwallis, an enthusiastic follower and admirer of Montaigne, refers to various translations from Montaigne that were circulating from hand to hand in manuscript. 
It was, however, John Florio's published translation that was responsible for Montaigne's success and for the growing popularity of the essay form in Elizabethan England. Francis Bacon, who published his Essays in 1597, borrowed the title from Montaigne and was the first to use the term "essay" as the designation of a genre, although he did not acknowledge his debt to the French author (Friedrich 1991:345). Bacon was swiftly followed by William Cornwallis who published two volumes of Essayes and characterized the genre in ways that would be reiterated through its history: "the essay as tentative practice work," "like a Scrivenor trying his pen," the result being prose that at best is "undigested motions" (Hesse 2006:222).

Moreover, Cornwallis is the first to assert his discipleship to Montaigne openly, frequently citing his master and recommending him for "profitable Recreation [...] most excellent [...] In a word he hath made Morall Philosophy speake courageously, and in steede of her gowne, given her an Armour; he hath put Pedanticall Schollerisme out of countenance, and made manifest, that learning mingled with Nobilitie shines most clearly" (cit. in Matthiessen 1931:107).

Cornwallis did not read Montaigne in French but, as he declared, perused it "translated into a stile, admitting as few idle words as our language will endure:"

It is well fitted in his new garment, and Montaigne speaks now good English [...] It is done by a fellow less beholding to nature for his fortune then witte, yet lesser for his face then fortune; the truth is, he looks more like a good-fellow than a wise man, and yet he is wise beyond either his fortune or education. (cit. in Matthiessen 1931:107)

Although Cornwallis does not directly indicate Florio as the translator of the copy, his language recalls that of Florio's Preface, particularly his statement that he had put Montaigne in "English clothes" and rendered his Essays in "true English" (A2).

The influence of the Essays in early modern England was not limited to the introduction and development of the essay genre, but was extended to the private household education of gentle and noble families. As Warren Boutcher has convincingly demonstrated in a series of essays on Montaigne, humanist learning, household education and the cultural transmission of continental books, 
Montaigne's Essays became in late sixteenth-century England "a printed template for élite individualism" (Boutcher 2002:251). The second half of the sixteenth century brought with it a new understanding of the élite individual:

This was the persona whose compellingly informal, free-ranging, occasion-specific mode of appropriation of classical wisdom aimed to define itself against and above the systems, types and routines of institutionalized arts pedagogy. This was, of course, attractive even to the aspiring mercantile family or to the élite scholar who was in practice dependent on a profession or on selling or bartering his skills. If you were an élite parent, you would attempt to buy and control this process of self-definition for your offspring by acquiring the right experts and the right extra-curricular books. (Boutcher 2002:251)

As a means of social differentiation the élite young would supplement their school or university education with a private household education, guided by tutors who were supposed to provide a custom-made extra-curricular programme which would include a wider use of continental books. In this context, the English translations of European works were marketed "both for inclusion in libraries dominated by continental books but including a significant proportion in vernacular languages (including English), and for purchase by those of less learned capacity who were collecting a European library in English" (Boutcher 2002:246).

This kind of education was even more relevant for gentlewomen and noblewomen who were educated only within the private space of the household. English translations were also significant for the majority of gentlewomen who could read only in their mother-tongue. The fact that Florio chose to dedicate his translation to a group of six noblewomen, three of them his former pupils, testifies not only to the importance of the patronage of aristocratic women in the period but also to the significance of noblewomen as readers of translations. Boutcher cites the relevant case of Lady Anne Clifford, a noblewoman of the period, who mentioned in her diary that her tutors would constantly read to her from Montaigne's Essays (2004:22). The role of the Essays in her education is memorialised in a triptych which depicts a copy of the English Essayes as part of her household education (Boutcher 2004:22-23). In his three dedications, Florio himself makes several 
references to the fact that he has been reading Montaigne's Essays with his noble patronesses in private tutorials.

\section{3. "Translata Proficit": Florio's Defence of the Practice of Translation}

"Shall I apologize translation?" this is the question that opens Florio's epistle "To the courteous reader," an epistle that takes the form of a most persuasive and vehement defence of the practice of translation. Quoting Giordano Bruno, his "olde fellow Nolano," "who taught publikely that from translation all science had its offspring," Florio rests his case all in favour of translation (A5). Drawing a kind of linguistic genealogical tree, he maintains that it was by means of translation that the names of the most popular Renaissance subjects were borrowed from the Greeks, who in their turn inherited them from the Egyptians who drew their own water from "the well-springs of the Hebrews or Chaldees" (A5). Thus, he challenges those who oppose translation into English to explain why these "well-springs" be so "sweete and deepe" for others and "sower and smell" for us (A5). Echoing the Protestant arguments offered for the benefits of translation into the vernacular, Florio argues that it is the duty of the learned, who are the only "worthy translators," to "unwrap learning" from its "learned mantle" and make it available to the English people (A5). The learned should willingly undertake this action unless they wish ignorance to be the basis of devotion and keep God far from the common people, the main consequences of praying and preaching in an unknown language:

Why, but it is not wel Divinite should be a childes or old wives, a coblers, or clothiers tale or table-talke. There is use, and abuse: use none too much: abuse none too little. Why but let Learning be wrapt in a learned mantle. Yea but to be unwrapt by a leaned nurse: yea, to be lapt up againe. Yea, and unlapt againe. Else, hold we ignorance the mother of devotion; praying and preaching in an unknowne tongue: as sory a mother, as a seely daughter: a good minde perhaps, but surely an ill manner. If the best be meete for us, why should the best be barrd? (Florio:A5)

Abbreviating the Latin proverb Translata proficit arbos (a tree makes progress when transplanted) and "wittingly" mistaking it, as he himself states, Florio preserves only its beginning and proudly states 
that translata proficit i.e. what is translated increases/augments /advances. ${ }^{1}$

Florio's argumentation shares the common Renaissance view of translation as a means of advancing, of developing, of increasing the language and culture of a nation. Starting with the second half of the sixteenth century, the educational role of translation began to be gradually supplemented by another one which seemed equally significant: the function of translation in the formation of the national language and identity.

If at the beginning of the sixteenth century, translators would still lament the inferiority of English to French, Italian and the other vernaculars, gradually, a new-found confidence in the powers of the English language emerged, especially as a result of the new expansionist policy initiated by Henry VIII and continued by Elizabeth I (Cronin 2007:256).

A sort of "cultural nationalism" (Burke 2007:19), the endeavour to equal and outdo the accomplishments of translators from neighbouring countries, out of local pride, urged mid- and late sixteenth century English translators to compete with prestigious vernacular languages such as French, Italian and Spanish. Thus, on the one hand, Thomas Hoby complains about the fact that English is lagging behind the other vernacular languages and, on the other, emphasises the superiority of his own translation over those of translators from other countries who, unlike him, did not preserve the integrity of the text. The English translators' awareness of the need to enrich their language and culture is also proven by the high number of imports from Italian, French and Spanish as opposed to the exports which were extremely low before the 166os. The few translations from English into other vernaculars were often made by Englishmen, since most continental Europeans did not know English (Burke 2007:23). It is within this larger context that we have to understand Florio's defence and promotion of translation as well as his belief that every language has its Genius and inseparable form, which cannot be rendered exactly into another language without being altered ( $\left.\mathrm{A}_{5}\right)$.

\footnotetext{
${ }^{1}$ My translation.
} 
Florio further develops and expands the outline of his defence by inserting a set of arguments meant to support and protect honest translators against accusations of plagiarism and theft:

If nothing can be now sayd, but hath beene saide before (as hee sayde well) if there be no new thing under the Sunne. What is that that hath beene? That that shall be: (as he sayde that was wisest) What doe the best then, but gleane after others harvest? borrow their colors, inherite their possessions? What doe they but translate? perhaps, usurpe? at least, collect? if with acknowledgement, it is well; if by stealth, it is too bad: in this, our conscience is our accuser; posteritie our judge: in that our studie is our advocate, and you Readers our jurie. $\left(\mathrm{A}_{5}\right)$

Due to the early modern literal resonances of translation as transporting, carrying, or conveying, and the subsequent association of the verbs to translate and to convey with the meaning of the word theft, the distinction between imitation and theft became rather blurred in the sixteenth century when a new awareness about authorship and the status of the author emerged:

Accusations of translation as pilfering were indeed frequent in the sixteenth century; and they increased along with the articulation of notions of authorship, authority and intellectual property, in a century that witnessed the shift from early humanist doctrines of faithful copying or imitatio to the development of the more modern sense of plagiarism (Parker 1996:137).

The verb to translate preserves in early modern English the double sense it has in Latin: that of linguistic transfer and physical transport, of carrying an object from one place to another (Parker 1996:137). Both senses are carefully rendered in Florio's 1598 Italian-English dictionary; under the entry of tradurre we find the following explanations:

to bring, to turne, to convert, to convay from one place to another, to bring over. Also to translate out of one tongue into another. Also to bring, convert, or transport from one to another, to leade over, to displace and remove from one place to another, to transpose. (Florio 1598:426)

This polysemous understanding of the verb to translate is one of the reasons why translation in the period could be so easily associated with the stealing of lines or plots (Parker 1996:137). Ben Jonson is one of the dramatists who frequently refer to translation as theft. In Poetaster, this idea is highlighted in the lines in which Demetrius 
accuses Horace of stealth: "I could tell you he were a translater |I know the authors from whence he has stole" (V.3.304-306).

It is in this context that we have to understand Florio's emphasis on the idea of an honest translator. Although translation involves borrowing, collecting or even usurping the original text, the work is, in his opinion, legitimate as long as translators acknowledge their sources. In the dedication to the countess of Bedford, Florio criticises Montaigne, "his maister," for not having identified the quotations he used in his essays $\left(\mathrm{A}_{3}\right)$. At the same time he expresses his endless gratitude to Dr. Matthew Gwinne, "his onelie dearest and in love-sympathising friend," who helped him translate and trace to their sources all the quotations from "ancient or modern" authors that abound in Montaigne's work ( $\mathrm{A}_{3}$ ).

As long as the sense is preserved and the translator is not a thief, the fact that, for instance, Florio himself "made of good French no good English" is not utterly reprehensible. Therefore, Florio is more concerned with rendering the sense of the original text rather than its form, showing to his reader Montaigne's horse without "its trappings," "the meat without the sauce" (A5). Accordingly, he confesses that he did not amend the text of his translation and claims that if there are errors in the text, they are either the author's "if of matter" or the printer's "if of omission" ( $\left.\mathrm{A}_{5}\right)$. Reinforcing the translator's responsibility for the meaning of the text, Florio states that he can be blamed for those errors which have to do with grammar or orthography; most importantly "if any be capitall in sense mistaking, be I admonished, and they shall be recanted" (A5). At the end of his letter Florio tries to forestall any possible criticism by challenging those who would find fault with his translation to surpass him.

\section{The Translator as the Foster-Father of Translation}

Florio manifested his interest in matters of language, translation and cultural transpositions well before his translation of the Essays. His first published book, Florio's First Fruits (1578), a language-learning dialogue book, opens with a substantial amount of introductory material on Italian and English, followed by dialogues arranged in forty-two chapters of varying lengths, a brief vocabulary, prayers, rules for Italians to follow in pronouncing English, and an Italian 
grammar. It was followed in 1591 by Florio's Second Fruites and by Giardino di ricreatione, a collection of Italian proverbs. However, his most important linguistic and cultural enterprise was the publication of his Italian-English dictionary, A Worlde of Wordes (1598), whose expanded version was published in 1611 and dedicated to Queen Anne herself. ${ }^{2}$

In the dedication that prefaces the first book of the Essays, Florio develops the way in which he understands the role and status of the translator and his relationship to the original author. Various translation scholars have noticed and interpreted the rich, international storehouse of metaphors, images and analogies that were used in the early modern prefaces and dedicatory epistles to describe the act of translation. In his essay on the practice of translation in the Renaissance, Yehudi Lindeman suggests that "theoretical principles are buried inside the metaphors" and that a scholar interested in the Renaissance theory of translation should "be able to get to them, independent of the number of texts examined" (1981:206). Theo Hermans similarly acknowledges that "the images appear to be highly functional and that they form an integral and essential part of the Renaissance theory of translation" (1997:105) and claims that "[t]hey bear on the very possibility of translation as well as on the relation between the translation and its original and between the translator and his audience" (1997:105). Massimiliano Morini devotes an entire chapter of his book on Tudor translations to the use of figurative language in the discourse about translation, arguing that those few sixteenth-century definitions of translations should be searched for and excavated "out of the figures which are used by translators in order to describe the process of translation, some of its stages, or the difficulties encountered in translating one particular text" (2006:35).

Consequently, Florio's extensive use of metaphors and similes in his exposition and description of the practice of translation is highly typical of the Renaissance practice. In the dedication that precedes the first book of the Essays, Florio compares the process of translation to that of giving birth to a baby, a birth which is, unsurprisingly, masculine "as are all men's conceipts that are their

\footnotetext{
${ }^{2}$ For more details on Florio's life and work see Matthiessen (1931), Yates (1934) and Wyatt (2005).
} 
own, though but by their collecting" (A2). The act of translation and its delivery are described in mythological terms. Florio compares himself to Vulcan, the god of beneficial and hindering fire and god of artisans, who had delivered Minerva, the goddess of wisdom, in a most unusual manner. Suffering from a painful headache, Jupiter asked Vulcan to use his axe to split open his head to relieve the pressure; when he did that, out sprang goddess Minerva, fully grown, wearing armour and ready for battle (A2).

Just like Vulcan, Florio had to hatchet his translation from that "Jupiters bigge braine" (A2), in his case Montaigne's, the original author. By comparing himself to Vulcan, Florio suggests that his actions in translating were as "simple and straightforward as Vulcan's in breaking open his lustful father's head. The desired object - Montaigne's Essays - pre-existed; the process of translation was only a matter of removing it from the vessel which contained it" (Pascoe 2001:162).

According to Theo Hermans, the metaphor that described translation as pouring something from one vessel into another was frequently employed by Renaissance translators as it pointed not only to the transfer of meaning but also to the idea of "decanting" which inevitably involved "spilling or loss of quality to the content" (1997:121).

Nevertheless, the idea of easy liberation is further on countered by Florio's account of the pains and difficulties he had to go through until he managed to finish his translation, pains that recall the labours of a real child-birth: "I sweat, I wept, and I went-on, til now I stand at bay"(A2). Consequently, Florio casts himself in the role of a "fondling foster-father;" his appropriation of the paternity of the text emphasises the act of translation not as a simple transfer, but, on the contrary, as the rewriting of the text into a new creation.

In order to describe the process that involved the appropriation of the text, its "domestication," Florio resorts to another typical, early modern metaphor related to the field of clothing and to the idea of translation as an act of re-dressing the original text. According to Morini, the implication of this metaphor is "that meaning and words can be separated in the original text as well as in the translation: words being but the vestment of thought, they are seen as the least 
essential part of writing, the one that can be disregarded without great loss in the activity of translation" (2006:36).

Translation becomes a new-born baby whom Florio, the loving foster-father, has "transported" from France to England, has put "in English clothes" and taught to "talke our tongue:"

So to this defective edition (since all translations are reputed femalls, delivered at second hand; and I in this serve but as Vulcan, to hatchet this Minerva from that Iupiters bigge braine) I yet at least a fondling foster-father, having transported it from France to England; put it in English clothes; taught it to talke our tongue (though many-times with a jerke of the French Iargon) would set it forth to the best service I might. (A2)

At first glance, Florio's description seems to be a definition of "domestication" (Venuti 1995:1) avant la letter, aiming to move the author towards the reader rather than vice versa. However, Florio also mentions that he frequently gave his translation "a jerke of the French jargon" (A2). Thus, we may assume that what he endeavours to attain is similar to the "middle way" between domestication and foreignization that Goethe described as being the ideal type of translation two centuries and a half later. ${ }^{3}$

\section{In Between ...}

In rendering Montaigne's text Florio seems to be torn between his attempt to follow the original text closely, to render its meaning faithfully and his endeavour to make it comply with the Elizabethan dominant poetics which was characterised by a fondness for copia and equated fine writing with ornamentation, poetic complexity and the development of rhetoric. Most scholars have noticed his insatiable delight in words and consequently have focused on identifying the numerous instances in which Florio expands, augments and amplifies Montaigne's text by means of doubling,

\footnotetext{
3 "[T]here are two maxims in translation: one requires that the author of a foreign nation be brought across to us in such a way that we can look on him as ours; the other requires that we should go across to what is foreign and adapt ourselves to its conditions, its use of language, its peculiarities. The advantages of both are sufficiently known to educated people through perfect examples. Our friend, who looked for the middle way in this, too, tried to reconcile both, but as a man of feeling and taste he preferred the first maxim when in doubt" (Goethe 1992:78).
} 
paraphrasing and other euphuistic devices (Matthiessen 1931:127; Morini 2006:84). While his typical Elizabethan passion for words and extravagant speech cannot be denied, it should however be noticed that there are also plentiful examples of Florio's verbatim translation of Montaigne's text. As Morini observes, Florio is generally regardful of the overall integrity of the source text. He translates all the essays, he respects their order and keeps to the main lines of Montaigne's thought without cutting or amending any important passages. "While he keeps Montaigne's inventio and dispositio intact, his elocutio is transformed and adapted to match Florio's taste and the habits of his audience" (Morini 2006:84).

In order to give emphasis, to qualify, to concretize an image or simply to establish an emotional tone not found in Montaigne, Florio adds words, clauses and even sentences to achieve the desired effect. In the essay De la cruauté, Montaigne comments on the different temperaments and traits of character that distinguish the Italian soldiers from the Spanish, German and Swiss ones. Being coarser and heavier than the Italians or the Spanish soldiers, the Germans and the Swiss don't have the quick sense to reassess and reconsider a situation, not even when they are overwhelmed under the blows:

Mais que les Allemans et les Souysses, plus grossiers et plus lourds, n'avoyent le sens de se raviser, à peine lors mesmes qu'ils estoyent accablez soubs les coups. (1965:426)

Florio chooses to render Montaigne's rather neutral image "accablez soubs les coups" by the more concrete, visual and dramatic "overwhelmed with miserie, and the axe readie to fall on their heads" (246).

In the same paragraph, Florio translates Montaigne's "les apprentis" with the long and complicated explanation "new trained souldiers, and such as are but novices in the trade" (246). Similarly, Montaigne's consideration that novices in the business of war "se jettent bien souvent aux hazards, d'autre inconsideration qu'ils ne font apres y avoir esté eschauldez" (1965:426) is rendered in English by the amplified phrase "[novices] doe often headlong and hand over head cast themselves into dangers, with more inconsideration than afterward when they have seene and endured the first shocks, and are better trained in the schoole of perils" (246). 
In the essay, L'Heure des parlemens dangereuse, Montaigne argues that it has always been hazardous to trust the license of a victorious army and allow its soldiers free entry into the town:

Et a tousjours esté conseil hazardeux, de fier à la licence d'une armee victorieuse l'observation de la foy, qu'on a donnee à une ville, qui vient de se rendre par douce et favorable composition, et d'en laisser sur la chaude, l'entree libre aux soldats. (1965:28)

This time Florio inserts no fewer than three adjectives to characterize the unleashed soldiers, an image that strongly evokes Shakespeare's Henry V's speech to the citizens of Harfleur:

And it was ever a dangerous counsell to trust the performance of word or oath given unto a Citie, that yeelds unto gentle and favourable composition, and in that furie to give the needie, bloudthirstie, and prey-greed Souldier free entrance into it, unto the free choise and licence of a victorious armie. (20)

Many readers have identified the influence of Lyly's euphuism in Florio's fondness for addition, paraphrase, symmetry, alliteration and parallelism; Frances Yates also points to the possible influence of the Arcadian style, with its extravagantly meandering phrases and liking for repetition and alliteration (1934:226). F.O. Matthiessen explains this overflow of compound words by pointing to the flourishing popularity in Elizabethan England of the style of the Huguenot poet Du Bartas, especially his fondness for creating compound words and ornate constructions (1931:123).

When Florio translates, for instance, Montaigne's "ny plus ennemy des remuëments et nouvelletez de son temps" (1965:194) as "nor a sharper enemie of the changes, innovations, newfangles, and hurly-burlies of his time" (96), he does not add any new meaning to Montaigne's, his only purpose being to ornate his style.

Nevertheless, doubling also performs a didactic function. In the Epistle to the Reader, Florio warns his English audience that he introduced in the translation some "uncouth terms," borrowed from French, with the acknowledged purpose of enriching and enlarging the English vocabulary $\left(\mathrm{A}_{5}\right)$. Since some of these words could be unfamiliar to certain members of his audience, Florio uses doubling and sometimes tripling to link them to a more common English word. The examples are manifold: "sorceries and witchcrafts" (42) for the French sorcellerie, "bastion or skonce" (12) (Fr. un bastion), 
"extinguish and suppresse" (96) (Fr. esteindre), "the acquisition and purchase" (618) (Fr. l'acquisition).

Florio's tendency to employ these "uncouth terms" instead of more common English synonyms sets him in opposition to those Elizabethan scholars and translators who strongly opposed the borrowing of new words from other foreign languages.

Thomas Hoby's translation of Castiglione, for instance, bears not only the marks of the new humanist emphasis on an exact and clear rendering of the original texts "without idle words," "without dark sense" (Morini 2006:17), but also the powerful influence of the purist Sir John Cheke who, along with other intellectuals like George Puttenham, Thomas Wilson and Roger Ascham, advocated the use of Old English words against the use of Latin neologisms and other "inkhorn terms." This group of scholars fought for good education, for classical scholarship, for the purity of written English and first and foremost "for the strength and worth of the native English character which they felt was menaced by the reckless practice of assimilation which seized young England face to face with the allurements which reached it from abroad" (Mair 1909: xxvii).

In the letter attached to Hoby's translation of Il Cortegiano, John Cheke takes Hoby's translation as a point of departure for a detailed defence of his linguistic policy:

I am of this opinion that our own tung should be written cleane and pure, unmixt and unmangeled with borowing of other tunges; wherein if we take not heed by tijm, ever borowing and never paying, she shall be fain to keep her house as bankrupt. For then doth our tung naturallie and praisablie utter her meaning when she boroweth no counterfeitness of other tunges to attire herself withall, but useth plainlie her own, with such shift as nature, craft, experiens and following of other excellent [writers] doth lead her unto. (1561:810)

Supposing that the translator does not manage to coin a new word by using the "mould of our own tongue" or by finding an equivalent in the old English language, only then is he allowed to borrow "with bashfulness" from another language. In order to consolidate and subtly endorse Cheke's position and arguments as well as his own attitude towards these issues, ${ }^{4}$ Hoby placed Cheke's letter precisely

${ }^{4}$ Hoby had been Cheke's disciple. 
before the Epistle of the Author in which Castiglione, himself a bold champion of the vernacular, ardently argued against the practice of forging and borrowing new words from other languages. To justify his own choice of words when writing The Courtier, Castiglione claimed that because of the borrowing practice the Tuscan language included numerous French, Spanish and provincial words which were no longer understood by the Tuscans themselves. Unlike people in Tuscany, who used "many words cleane corrupte from the Latin," those in other Italian regions, such as Lombardy and other parts of Italy, preserved the words "wholl and without any change at all." Therefore, he did not consider himself in error for having eschewed all newfangled words in his writing and preferred to take "the whole and pure word of mine own Countey, than the corrupt and mangled of another" (1561:811).

Several other English intellectuals and writers, such as Thomas Wilson and George Puttenham, shared John Cheke's views on the nature of language and the appropriate means of enriching it. In the first book of The Arte of Rhetorique (1560), a treatise based on the theories of Quintillian and Cicero, Thomas Wilson claims that a skilful orator should teach, delight and persuade. Accordingly, the lessons of plainness, order, and directness have to be duly enforced, if one wishes to delight or win over (Wilson 1560: Book 1). The debate about the use and abuse of "inkhorn" terms - neologisms and far-fetched words borrowed mainly from Latin but also from French and Italian- was revived in any discussion about language, rhetoric or translation. ${ }^{5}$ In a classic passage on Plainesse, what it is, Wilson makes a rough attack on inkhorn terms and illustrates the fault by quoting a burlesque letter overloaded with such words (Wilson 1560: Book 3).

In The Arte of English Poesie (1589), George Puttenham similarly attacks the reckless use of "inkhorne" terms and advises poets to avoid strange terms borrowed from other languages:

Albeit peradventure some small admonition be not impertinent, for we finde in our English writers many wordes and speaches amendable, and ye shall see in some many inkhorne termes so ill affected brought in by men of learning as preachers and

\footnotetext{
${ }^{5}$ For a more extensive discussion on the debate between the Latinists and the purists see Hughes (2000:ch. 4).
} 
schoolemasters: and many straunge termes of other languages by Secretaries and Marchaunts and trauailours, and many darke wordes and not usuall nor well sounding, though they be dayly spoken in Court. Wherefore great heed must be taken by our maker in this point that his choise be good. (1589:121)

Translators themselves held different opinions on the use and utility of "inkhorn terms." Thus, Arthur Golding argues against borrowing words from other languages and makes a case in favour of forming new words from Anglo-Saxon sources. In The Dedicatory Preface, speaking of his own choice of words in his translation of Philip of Mornay, Golding maintains that he used accessible terms so that he should not obscure any further the meaning of the text which was already difficult to grasp in some cases (Golding 1587: $3 \mathrm{v}$ ).

On the other side of the barricade, translators like George Pettie, one of the boldest advocates of the use of inkhorn terms as a means of enlarging the English vocabulary, claim that there is no justified reason in refraining from using them since "it is indeed the ready way to enrich our tongue and make it copious" (Pettie 1586: n.p.). As already mentioned, in his address "to the courteous reader" Florio himself admits that he introduced a number of French terms in his translation in order to render them familiar to the English audience:

or are they in some uncouth termes; as entraine, conscientious, endeare, tarnish, comporte, efface, facilitate, ammusing, debauching, regret, effort, emotion, and such like; if you like them not, take others more commonly set to make such likely French words familiar with our English, which well may beare them. (A5)

Borrowing went hand in hand with the use of an abundance of compound words - another feature that Florio shares with his Elizabethan contemporaries. Whenever possible, he uses and even invents compounds. Thus, for the French "lourds" (1965:426) he uses "leaden-headed" (246); Montaigne's "des ames si monstrueuses" (1965:432) becomes "so marble-hearted and savage-minded men" (237); "une mort plus aspre et insupportable" (1965:432) becomes "a more sharply-cruell and intolerable death" (238); "pandans et glissans" (1965:644) is rendered as "downe-hanging and slippery" (374), "trop bonne opinion" (1965:631) becomes "over good conceit and selfe-weening opinion" (368); "affamé" (1965:199) is translated as "hunger-starven" (98); "veuë nette et bien purgée," (1965:1037) is rendered as "a cleere, farre-seeing and true-discerning sight" (618), etc. 
Nevertheless, Florio's fondness for doubling and compound words is complemented by numerous passages in which he keeps very close to the French original, frequently rendering the text almost word for word. When analysing the translation, we focused particularly on those essays in which Montaigne reworks and discusses topics and ideas that could be linked to Machiavelli's discourse on the figure of the prince (1513). All the examined passages were faithfully rendered with no interpolations on the part of the translator. Thus, when perusing the bi-text of the essay, De l'utile et de l'honeste, we have noticed that Florio makes very few unnecessary additions and renders the text verbatim:

De mesme, en toute police: il y a des offices necessaires, non seulement abjects, mais encores vicieux: Les vices y trouvent leur rang, et s'employent à la cousture de nostre liaison: comme les venins à la conservation de nostre santé. S'ils deviennent excusables, d'autant qu'ils nous font besoing, et que la necessité commune efface leur vraye qualité: il faut laisser jouer cette partie, aux citoyens plus vigoureux, et moins craintifs, qui sacrifient leur honneur et leur conscience, comme ces autres anciens sacrifierent leur vie, pour le salut de leur pays: Nous autres plus foibles prenons des rolles et plus aysez et moins hazardeux: Le bien public requiert qu'on trahisse, et qu'on mente, et qu'on massacre: resignons cette commission à gens plus obeissans et plus soupples. (1965:790)

In matter of policy likewise some necessary functions are not onely base, but faulty: vices finde therein a seate and employ themselves in the stitching up of our frame; as poysons in the preservations of our health. If they become excusable because wee have neede of them, and that common necessity effaceth their true property; let us resigne the acting of this part to hardy Citizens, who sticke not to sacrifice their honours and consciences, as those of old, their lives, for their Countries availe and safety. We that are more weake had best assume taskes of more ease and lesse hazard. The Common-wealth requireth some to betray, some to lie, and some to massaker: leave we that commission to people more obedient and more pliable. (476)

The above quoted passage faithfully renders Montaigne's profoundly Machiavellian understanding of the necessities of political life which presuppose sacrificing one's honour and conscience and possessing the ability to "betray," "lie" and "massaker." Another passage that markedly echoes Machiavelli's 
Realpolitick understanding of instrumental reason is likewise rendered literally, Florio following closely not only the sense but even the words of Montaigne's text (De la Vanité):

La vertu assignée aux affaires du monde, est une vertu à plusieurs plis, encoigneures, et couddes, pour s'appliquer et joindre à l'humaine foiblesse: meslee et artificielle; non droitte, nette, constante, ny purement innocente. Les annales reprochent jusques à ceste heure à quelqu'un de nos Roys, de s'estre trop simplement laissé aller aux consciencieuses persuasions de son confesseur. Les affaires d'estat ont des preceptes plus hardis. [...] Celuy qui va en la presse, il faut qu'il gauchisse, qu'il serre ses couddes, qu'il recule, ou qu'il avance, voire qu'il quitte le droict chemin, selon ce qu'il rencontre. (1965:991)

The vertue assigned to the worlds affaires, it is a vertue with sundry byases, turnings, bendings and elbowes, to apply and joyne it selfe to humane imbecilities mixed and artificiall; neither right, pure or constant, nor meerely innocent. Our Annales even to this day blame some one of our Kings to have over-simply suffered himself to be led or misled by the conscientious perswasions of his Confessor. Matters of state have more bold precepts.[...] He that goeth in a presse or throng of people must sometimes step aside, hold in his elbowes, crosse the way, advance himselfe, start backe, and forsake the right way according as it falls out. (593)

In the end, we would like to add one last example which, at first glance, could seem to be an instance of Florio's amplifying technique:

Although our spirituall and corporall Physitians: as by covenant agreed upon betweene them, finde no way of recoverie, nor remedies for diseases of body and minde, but by torment, griefe and paine, watching, fasting, haire-shirts, farre and solitarie exile, perpetuall prison, roddes and other afflictions, have therefore beene invented: But so, that they be truly afflictions, and that there be some stinging sharpnesse in them. (99)

However, when compared to Montaigne's original, we discover that Florio is actually following the source text word for word:

Quoy que noz medecins spirituels et corporels, comme par complot faict entre eux, ne trouvent aucune voye à la guerison, ny remede aux maladies du corps et de l'ame, que par le tourment, la douleur et la peine. Les veilles, les jeusnes, les haires, les exils lointains et solitaires, les prisons perpetuelles, les verges et autres 
afflictions, ont esté introduites pour cela: Mais en telle condition, que ce soyent veritablement afflictions, et qu'il y ait de l'aigreur poignante. (1965:200)

Examples of Florio's literal translation can be multiplied just like those which testify to his fondness for words. Our aim in this paper was to emphasise that one should not regard Florio's translation as an incoherent text overflowing with additions and interpolations, but as a translation which attempts to find a middle way between adapting Montaigne's Essays to the taste of the Elizabethan audience, making it comply with the dominant poetics of the time, and respecting the integrity of Montaigne's text. It is safe to assume that Florio's responsibility in rendering Montaigne's text as faithfully as possible must have been enhanced by the fact that, as he himself states in the dedication prefaced to the first book, his patrons and patronesses were fairly well acquainted with the French original.

\section{References}

Boutcher, Warren 2002. "Humanism and Literature in Late Tudor England: Translation, the continental book and the case of Montaigne's Essais." Ed. Jonathan Woolfson. Reassessing Tudor Humanism. Basingstoke: Macmillan: 243-268.

- 2004. "Marginal Commentaries: The Cultural Transmission of Montaigne's Essais in Shakespeare's England." Ed. Jean-Marie Maguin. Montaigne et Shakespeare: vers un nouvel humanisme. Montpellier: Société Française Shakespeare: 13-27.

Burke, Peter 2007. “Cultures of Translation in Early Modern Europe." Eds. Peter Burke \& Ronnie Po-Chia Hsia. Cultural Translation in Early Modern Europe. Cambridge: Cambridge University Press: 7-38.

Castiglione, Baldassare 1561. The courtyer of Count Baldessar Castilio divided into foure books. Trans. Thomas Hoby. London: William Seres.

Cheke, John 1557. "A letter of John Cheke to Thomas Hoby" in Castiglione, Baldassare 1561. The courtyer of Count Baldessar Castilio divided into foure books. Trans. Thomas Hoby. London: William Seres: 810.

Cornwallis, William the Younger 1600. Essayes. London.

Cronin, Michael 2007. "Double Take: Figuring the Other and the Politics of Translation." Eds. Paul St-Pierre and Prafulla and C. Kar. TranslationReflections, Refractions, Transformations. Amsterdam/Philadelphia: John Benjamins: 253-262. 
Desan, Philippe 2004. "'Translata proficit': John Florio, sa réécriture des Essais et l'influence de la langue de Montaigne-Florio sur Shakespeare." Eds. Jean-Marie Maguin and Pierre Kapitaniak. Shakespeare et Montaigne: Vers un Nouvel Humanisme. Montpellier: SFS: 29-93.

Hesse, Douglas 2006. "British Essay." Ed. Tracy Chevalier. Encyclopedia of the Essay. Routledge: Taylor \& Francis e-Library: 220-238.

Florio, John 1598. A Worlde of Wordes, or Most Copious, and exact Dictionarie in Italian and English. London: Arnold Hatfield for Edw. Blount.

Friedrich, Hugo 1991. Montaigne. Trans. Dawn Eng. Berkley \& Los Angeles: University of California Press.

Goethe, Johann Wolfgang 1992 (1824). "Writings on Literature." In André Lefevere. Translation, History and Culture: A Source. London: Routledge: 78 .

Golding, Arthur 1587. "Dedicatry Preface" in A vvoorke concerning the trewnesse of the Christian religion, written in French: against atheists, Epicures, Paynims, Iewes, Mahumetists, and other infidels. By Philip of Mornay Lord of Plessie Marlie. Begunne to be translated into English by Sir Philip Sidney Knight, and at his request finished by Arthur Golding. London: imprinted by Charlewood\&Robinson for Thomas Cadman, *3v.

Hermans, Theo 1997. "The task of The Translator in the European Renaissance: Explorations in a Discursive Field." Ed. Susan Bassnett. Translating Literature. Cambridge: D.S. Brewer: 14-40.

Holland, Philemon 1601. "The Preface to the Reader." The Historie of the World, Commonly Called The Natural Historie of C. Plinius Secundus. Trans. Philemon Holland. London: Adam Flip: n.p.

Hughes, Geoffrey 2000. A History of English Words. Oxford: Blackwell Publishing.

Jonson, Ben 1995 (1601). Poetaster. Ed. Tom Cain. Manchester: Manchester University Press.

Lefevere, André 1992. Translation, Rewriting and the Manipulation of Literary Fame. New York: Routledge.

— \& Bassnett, Susan 1998. Cultures, Essays on Literary Translation. Clevendon: Multilingual Matters.

Lindeman, Yehudi 1981. "Translation in the Renaissance: A Context and a Map." Canadian Review of Comparative Literature 8/1: 204-216.

Machiavelli, Niccolò 2005 (1513). The Prince. Trans. Peter Bondanella. New York: Oxford University Press.

Mair, George Herbert 1909. "Introduction." Thomas Wilson. The Arte of Rhetorique. Oxford: Oxford University Press: v-xxxiv. 
Matthiessen, Francis Otto 1931. Translation: An Elizabethan Art. Cambridge, MA: Harvard University Press.

Montaigne, Michel de 1965 (1595). Les Essais. Ed. P. Villey and Verdun L Saulnier. Paris: Presses Universitaires de France.

_ 1603. The Essays or Morall, Politike and Millitarie Discourse of Lord Michaell de Montaigne. Trans. John Florio. London: Edward Blount.

Morini, Massimiliano 2006. Tudor Translation in Theory and Practice. Aldershot: Ashgate.

Parker, Patricia 1996. Shakespeare from the Margin: Language, Culture, Context. Chicago and London: University of Chicago Press.

Pascoe, David 2001. "The Dutch Courtesan and the Profits of Translation." Ed. T.F. Wharton. The Drama of John Marston. Cambridge: Cambridge University Press: 162-180.

Pettie, George 1586. "To the Reader." Civile Conversation of Stephen Guazzo. Trans. George Pettie. London.

Puttenham, George 1936 (1589). The Arte of English Poesie. Ed. Gladys Doidge Willcockand and Alice Walker. Cambridge: Cambridge University Press.

Stone, Jon R. 2005. The Routledge Dictionary of Latin Quotations. Aldershot: Routledge.

Venuti, Lawrence 1995. The Translator's Invisibility: A History of Translation. London and New York: Routledge.

Wilson, Thomas 1909 (1560). The Arte of Rhetorique. Ed. G. H. Mair. Oxford: Clarendon Press.

Wyatt, Michael 2005. The Italian Encounter with Tudor England: A Cultural Politics of Translation. Cambridge: Cambridge University Press.

Yates, Frances A. 1934. John Florio, the Life of an Italian in Shakespeare's England. Cambridge: Cambridge University Press.

How to cite this article:

Zaharia, Oana-Alis. “Translata Proficit: Revisiting John Florio's translation of Michel de Montaigne's Les Essais." SEDERI 22 (2012): 115-136.

Author's contact: oanaalispopescu@yahoo.com 